\begin{tabular}{|l|c|c|c|r|}
\hline $\begin{array}{l}\text { Cuadernos de Investigación Geográfica } \\
\text { Geographical Research Letters }\end{array}$ & 2017 & N $^{\circ} 43(1)$ & pp. 171-187 & $\begin{array}{r}\text { ISSN 0211-6820 } \\
\text { eISSN 1697-9540 }\end{array}$ \\
\hline
\end{tabular}

\title{
EROSION PROCESSES ON DIFFERENT RELIEF UNITS: THE RELATIONSHIP OF FORM AND PROCESS
}

\author{
T. ISERLOH ${ }^{1 *}$, S. WIRTZ ${ }^{1}$, M. SEEGER ${ }^{1}$, I. MARZOLFF ${ }^{2}$, J.B. RIES ${ }^{1}$ \\ ${ }^{1}$ Physical Geography, Trier University, Trier, Germany. \\ ${ }^{2}$ Physical Geography, Goethe University, Frankfurt am Main, Germany.
}

\begin{abstract}
Geomorphological relief units are related to certain processes and the history of their development. They are well defined by form and material. This study investigates erosion processes on different relief units. Rainfall simulations, rill experiments and monitoring by aerial photography were performed on dunes, glacis, Holocene fillings, talus material and Quaternary loam terraces in order to analyse the varying process intensities. Splash, interrill erosion and runoff generation were quantified by rainfall simulation experiments, rill erosion by rill experiments and gully growth by monitoring over several years. The test sites are situated in NE-and SE-Spain, S-Morocco and $N$-Burkina Faso. The results clearly show that the measured processes are very different from those supposed to be relevant for the formation of relief units. Dunes and Holocene fillings are highly erodible by splash and interrill erosion. In contrast, Quaternary loam terraces show a low susceptibility to erosion processes. We conclude that the relief units show very different dominances of erosion processes and process intensities. The differentiation is more significant with increasing scale and complexity of the erosion process: The extent of gully growth varies much more between the different units than those of splash and interrill erosion do.
\end{abstract}

Procesos de erosión en diferentes unidades del relieve: la relación entre forma y proceso

RESUMEN. Las unidades geomorfológicas están relacionadas con ciertos procesos y con la historia de su formación. Además, se definen por sus formas y materiales. En este estudio se investigan los procesos de erosión en diferentes unidades de relieve. Simulaciones de lluvia, experimentos en rigolas y seguimientos a través de fotografía aérea se llevaron a cabo en dunas, glacis, rellenos holocenos, taludes y terrazas franco-arcillosos de origen cuaternario, con el objeto de conocer la variación en la intensidad de los procesos. Para ello, se evaluaron el impacto de las gotas de lluvia, la generación de escorrentía, la erosión en inter-rigolas y rigolas durante varios años. Las áreas de estudio se situaron 
en el NE y SE de España, sur de Marruecos y norte de Burkina Faso. Los resultados muestras claramente que los procesos medidos son muy diferentes entre sí según la formación de las propias unidades de relieve. Las dunas y los rellenos holocenos en los valles son altamente susceptibles a la erosión por el impacto de las gotas de lluvia y la formación de regueros. Por el contrario, las terrazas sobre materiales franco-arcillosos muestran baja susceptibilidad a los procesos de erosión. Por lo tanto, se puede concluir que las distintas unidades de relieve muestran diferente dominancia e intensidad de procesos. Las diferencias son más significativas con el incremento de la escala y la complejidad del proceso erosivo: el crecimiento de las cárcavas varía mucho más entre diferentes unidades que los efectos del impacto de la gota de lluvia y la formación de rigolas.

Key words: relief units, erosion processes, rainfall simulation experiments, rill experiments, gully monitoring.

Palabras clave: unidades de relieve, procesos erosivos, simulación de lluvia, experimentos sobre cárcavas, monitoreo de cárcavas.

Received 20 December 2016

Accepted 14 March 2017

* Corresponding author: Thomas Iserloh, Physical Geography, Trier University, Trier, Germany. E-mail address: iserloh@uni-trier.de

\section{Introduction}

Terrain segmentation by means of the earth's surface morphology is a growing field of research since GIS and remote sensing data offer the possibility of gathering widespread topographical information at different scales (e. g. Minár and Evans, 2008; Pirotti, 2013). Hence, digital terrain data have found entry into many studies on hydrology and geomorphology (e. g. Drăguţ et al., 2009; Kawabata and Bandibas, 2009; Schwanghart and Scherler, 2014; Tarolli, 2014; Tarolli et al., 2015; Tarolli and Dalla Fontana, 2009; Wirtz et al., 2012a). The morphology of a landscape is the result of a process combination that has shaped the earth surface over a short or long period. Geomorphology is able to identify and classify a great variety of forms and their attributed processes. On the other hand, the topographical features of a landscape can be decisive for certain current processes.

The concept of hydrological response units (HRU), developed two decades ago by Flügel (1995), identifies and distinguishes different zones of differentiated hydrological behaviour. Among other characteristics of the study area it incorporates topographic information. In this concept, it was assumed that process variability within the delineated unit is lower than between different units. Following this concept, more recent approaches, have led to attempts of process types regionalisation (Hellebrand and van den Bos, 2008; Müller et al., 2009; Scherrer et al., 2007). 
A similar concept was adapted to erosion processes: Märker (2002) and Sidorchuk et al. (2003) defined erosion response units (ERUs). Until today the ERU concept has only been applied for the identification of areas prone to gully development and their subsequent use in gully-growth models. Recent studies aim at relating topographic characteristics to current processes and their prediction (Anders et al., 2009; Carr et al., 2015; Meissner et al., 2016). If recent efforts for automatic identification of relief units from digital terrain models (Anders et al., 2011; Martins et al., 2016; Smith et al., 2011) are taken into account, it is clear that relief units offer great potential for quantifying the current processes that shape the earth surface.

For this it is necessary to understand and quantify erosion processes that can be observed on different relief units with similar characteristics (e. g. similar genesis, topography and substrate). With the present study we intend to verify the following hypotheses:

- Certain relief units characterized by different materials and relief clearly differ in their current erodibility. Thus, the intensity of different erosion processes depends on the genesis, the substrate and even the age of the relief unit.

- The identification of the relationship between relief units and current process depends on the particular process, but also on the study method employed.

\section{Material and methods}

\subsection{Study areas}

We distinguished five relief units (dunes, glacis, Holocene fillings, talus material and Quaternary loam terraces) at eight study sites in Burkina Faso, Morocco and Spain (Fig. 1).

Table 1 summarizes the most important parameters of the different studied relief units. Slope ranges between $1^{\circ}$ and $15^{\circ}$, substrate varies between coarse material, sand, silt and clay. Regarding the age, the relief units cover the period between Plio-Pleistocene and today.

To research runoff generation and initial erosion processes, different types of measurements and experiments were carried out. In the following, the relief units and the methods applied are briefly described.

Table 1. Main characteristics of the different relief units.

\begin{tabular}{ccccc}
\hline Relief unit & Location & Slope & Substrate & Age \\
\hline Dune & Burkina Faso & $3-8^{\circ}$ & Sand & $18-11000$ BP \\
\hline Glacis & $\begin{array}{c}\text { Burkina Faso, } \\
\text { Morocco, Spain }\end{array}$ & $2-7^{\circ}$ & $\begin{array}{c}\text { Coarse material, } \\
\text { silt, clay }\end{array}$ & Plio-Quaternary \\
\hline Holocene filling & Spain & $1-5^{\circ}$ & Silt & Holocene \\
\hline Talus material & Spain & $8-15^{\circ}$ & Coarse material & Holocene, recent \\
\hline Quaternary terraces & Morocco & $1-3^{\circ}$ & Silt & $\begin{array}{c}\text { Late Pleistocene/ } \\
\text { Holocene }\end{array}$ \\
\hline
\end{tabular}




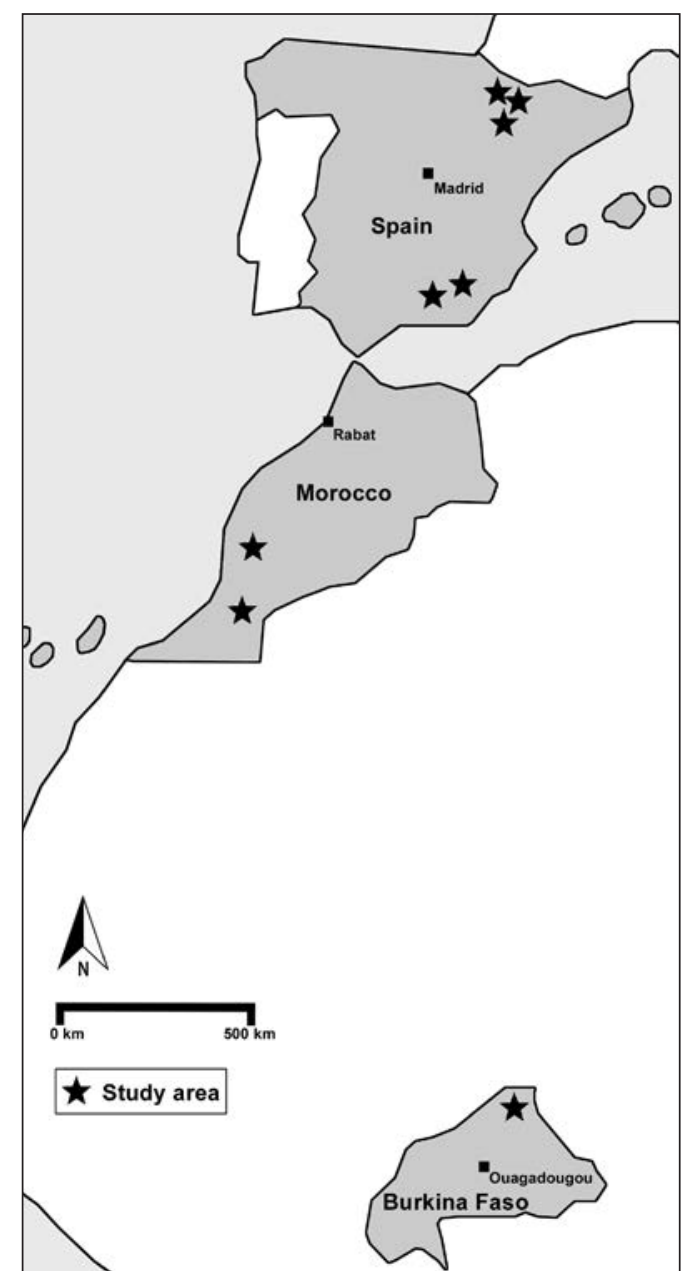

Figure 1. Location of the study sites. Black lines show national boundaries and coast lines, gray-shaded areas are national territories of Burkina Faso, Morocco and Spain, squares are capitals and stars are study sites.

\subsubsection{Dunes}

Currently remobilized Pleistocene dunes (Fig. 2a) occur in the north of Burkina Faso (province of Ouadalan). The dunes are composed of fine and medium sands accumulated in the late Pleistocene and transformed during the Holocene by intense pedogenetic processes. Without human impact, these dunes would be covered with dense grass vegetation. However, under current intense agricultural use with sorghum cultivation the surface tends to develop crusts due to intense erosion of the illuvial horizons. Even minor use - for example extensive grazing - leads to degradation processes with active sand movement. Thus small barchans, areas of deflation and slopes covered by recent sand accumulations are formed. 

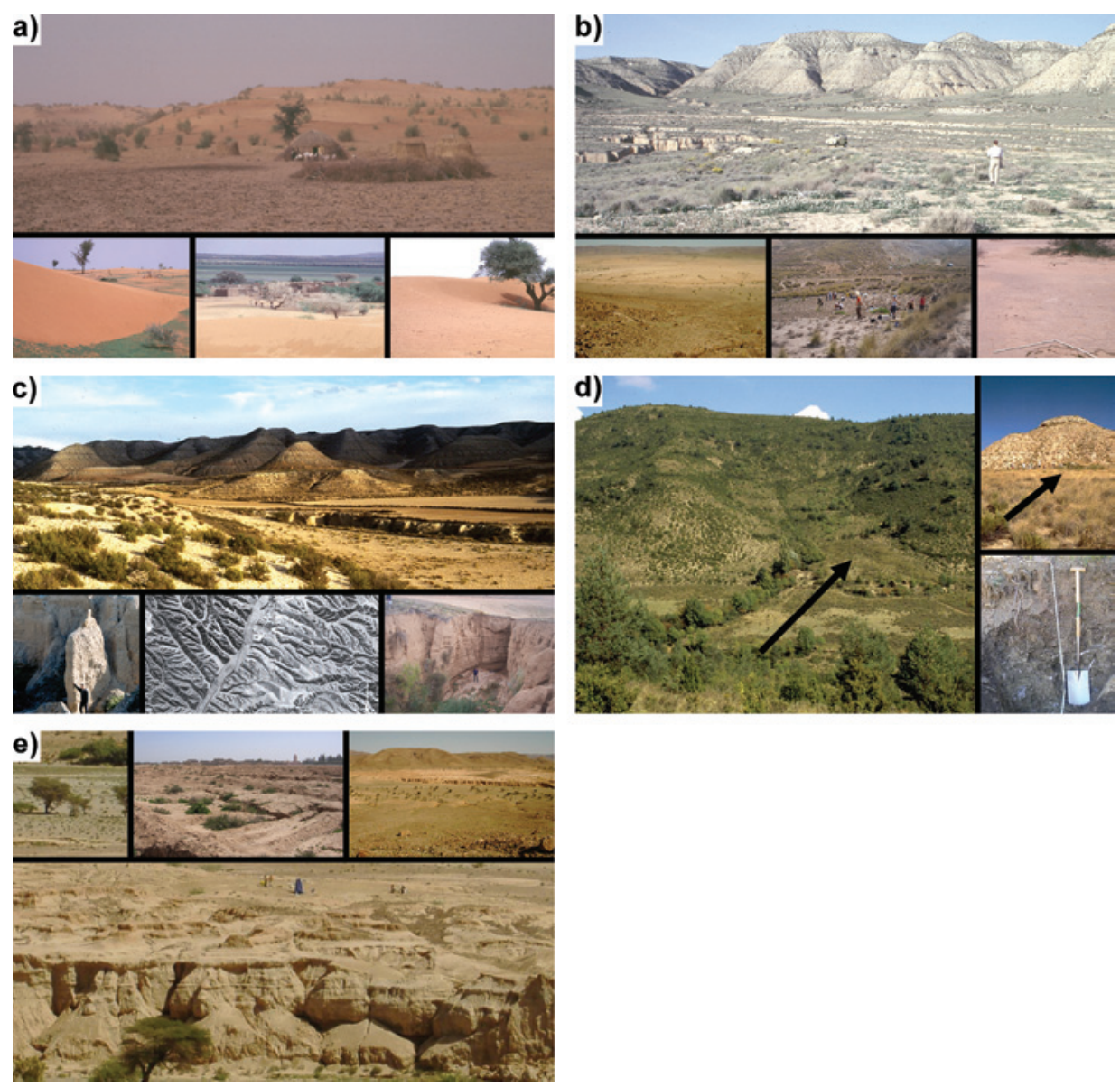

Figure 2. Photos of the five relief units listed in Table 1: a) dunes; b) glacis; c) Holocene fillings; d) talus material; e) Quaternary terraces.

\subsubsection{Glacis}

The glacis unit (Fig. 2b) is much more heterogeneous. Glacis are located at footslopes in the study sites of north-eastern and southern Spain. According to Spanish bibliography their origin is Plio-Quaternary (Peña Monné et al., 1993). Depending on slope position they are characterized by erosion (glacis d'érosion) or accumulation (glacis d'accumulation). Additionally, silty pediments in South Morocco and clayey glacis in Burkina Faso were observed. This unit presents a great range concerning criterions related to climate and substrate.

\subsubsection{Holocene filling}

Holocene fillings (Fig. 2c) are located in the study areas of the Iberian Peninsula. These are slightly sloped valley bottoms filled with eroded material from the surrounding 
slopes during periods of high erosive activity. The basis of these fillings has been dated to the Neolithic period (Andres et al., 2002), but the main sedimentation occurred during the Bronze and Iron Ages as well as the Roman colonization.

The material ranges from large masses of gravel to thick layers of silt. The latter dominates the presented study areas. These flat-bottomed valleys are in many places incised by active gully systems. When they are not under agricultural use, they are grazed with different intensities and show an irregular vegetation cover.

\subsubsection{Talus material}

The foot slopes flanking the Holocene fillings (Fig. 2d) are covered by talus material. It consists of fine material with high stone and rock content and can be considered as a sediment originating from current erosion processes (e. g. slides, solifluction and water erosion). This relief unit was investigated in the central Ebro Basin and the central Pyrenees in north-eastern Spain. Talus material is generally covered by sparse to dense scrubland and is extensively grazed in this region.

\subsubsection{Quaternary loam terraces}

Quaternary loam terraces (Fig. 2e) are researched in the Souss Basin and the Drâa Basin in southern Morocco. In the latter, the terraces are the most common landforms on the southern slopes of the Anti-Atlas. They are connected, frequently without a change in slope, with the superior glacis. Nowadays, they are affected by the torrential regime descending from Atlas and Anti-Atlas.

These loam terraces are very similar to the Holocene fillings described above, but their age has not yet been determined. Pedologic findings indicate that their formation dates from the Pleistocene/Holocene transition. Due to dry climatic conditions they are bare of vegetation.

\subsection{Quantification of erosion processes}

\subsubsection{Splash, interrill erosion and runoff generation}

We performed 160 field rainfall simulations to investigate runoff generation and initial soil erosion by splash and interrill erosion on the different relief units.

The small portable rainfall simulator used in this study is described in detail by Iserloh et al. (2012) and is very common in Europe (e. g. Cerdà et al., 2016; Iserloh et al., 2013a, 2013b; Prosdocimi et al., 2017; Rodrigo Comino et al., 2016). A calibrated uniform and reproducible rainfall (intensity $=40 \mathrm{~mm} \mathrm{~h}^{-1}$ ) is sprayed on a circular plot (d $=60 \mathrm{~cm}, \mathrm{~A}=0.28 \mathrm{~m}^{2}$ ) by a nozzle. The total runoff and eroded material produced during a 30-minute experiment is collected at 5-minute intervals. The amount of eroded material is weighted after filtering and drying at $105^{\circ} \mathrm{C}$. Key data in this study are the runoff coefficient (RC), the amount of eroded material expressed in $\mathrm{g} \mathrm{m}^{-2}$ and the suspended sediment load concentration (SSC) in $\mathrm{g} \mathrm{L}^{-1}$. 


\subsubsection{Rill erosion}

The erosion caused by concentrated flows generates rills of small dimensions $(<$ $1 \mathrm{~m}$ of width and depth) that are able to reach several tens of meters in length. The development of these rills may increase erosion rates to an order of magnitude higher than erosion caused by non-concentrated surface flows (Cerdan et al., 2002; Merz and Bryan, 1993; Nouwakpo et al., 2016b; Poesen, 1987; Wirtz et al., 2012a). Because of their highly erratic appearance and their easy destruction through soil management, erosion processes in rills are difficult to quantify (Casalí et al., 2006; Nouwakpo et al., 2016a; Wells et al., 2016).

To measure the effectiveness of linear erosion processes and for comparison with other measurements and experiments, rill experiments were developed and described in detail by Wirtz et al. (2010) and applied in several studies (Wirtz et al., 2013a, 2013b, 2012a, 2012b). As described in Wirtz et al. (2010), we discharged 72 liters of water with a flow rate of $9 \mathrm{~L} \mathrm{~min}^{-1}$ to a pre-existing rill. At three measuring points, water depth was recorded at different times of the experiment and sediment samples were collected. At the end of a defined distance from the starting point, runoff was continuously recorded. In addition, water velocity was recorded at the runoff front as well as through tracers at pre-defined moments. For rill characterization, slope was measured in segments of $1 \mathrm{~m}$ and detailed cross-sectional profiles were recorded at the sampling points. The eroded material was determined by filtration of the samples in laboratory. Similarly to the rainfall simulation experiment, the amount of eroded material was weighted after filtering and drying at $105^{\circ} \mathrm{C}$. Key data for this study are the mean suspended sediment load concentration (SSC) in $\mathrm{g} \mathrm{L}^{-1}$ and the runoff coefficient normalized in relation to the length of the gully (R-L). The factor R-L in $\mathrm{L} \mathrm{L}^{-1} \mathrm{~m}$ is a specific runoff coefficient related to flow length and can be interpreted as inverse value of the infiltration in the rill. Thus it is an expression of the hydraulic activity.

Although rill erosion does occur, no data was available for the dunes in Burkina Faso because no rill experiments were performed.

\subsubsection{Gully erosion}

Gully erosion is difficult to quantify because of the size and complexity of the forms as well as the tempo-spatial variability of their development. Moreover, gully growth is the result of many different processes, such as headwall retreat, lateral collapses and incision. For the quantification of gully-erosion processes, detailed aerial photographic monitoring has proved to be the most efficient method (d'OleireOltmanns et al., 2012; Eltner et al., 2016; Marzolff et al., 2011; Marzolff and Poesen, 2009; Marzolff and Ries, 2007; Ries and Marzolff, 2003; Stöcker et al., 2015; Wang et al., 2016). For this study we were able to use annual or semi-annual photographic series since 1995. Analogue and later digital photographs were taken from different camera carriers (hot-air blimps, kites and drones). After image rectification and photogrammetric evaluation, it was possible to document in detail the longitudinal and lateral growth of gullies, as well as incision and sedimentation in the system. In order to be able to make comparable measurements between different gully systems in 
the study presented here, the quantification of the dynamics has been limited to their headcuts. Key data are maximum annual gully growth $\left(\mathrm{R}_{\max }\right)$, the mean annual gully growth $\left(\mathrm{R}_{\text {mean }}\right)$ and the gully growth (Area loss).

\section{Results}

\subsection{Splash, interrill erosion and runoff generation}

The highest runoff coefficients were measured on dunes, with a median of $45 \%$. However, these relief units also showed the highest variability (Fig. 3). On Holocene fillings, the median runoff was very similar (median $\mathrm{RC}=41 \%$ ) but much more homogeneous. Runoff generation was considerably less on glacis $(30 \%)$, Quaternary loam terraces $(29 \%)$ and talus material $(23 \%)$.

Very similar to the runoff behavior but more homogeneous was the production of eroded material. The highest values were found on dunes $\left(24 \mathrm{~g} \mathrm{~m}^{-2}\right)$, Holocene fillings $\left(19 \mathrm{~g} \mathrm{~m}^{-2}\right)$ and Quaternary terraces $\left(16 \mathrm{~g} \mathrm{~m}^{-2}\right)$. The measured sediment amounts were an order of magnitude lower on glacis and talus material $\left(2.1 \mathrm{~g} \mathrm{~m}^{-2}\right.$ and $\left.1.4 \mathrm{~g} \mathrm{~m}^{-2}\right)$ and also showed a much lower variability.
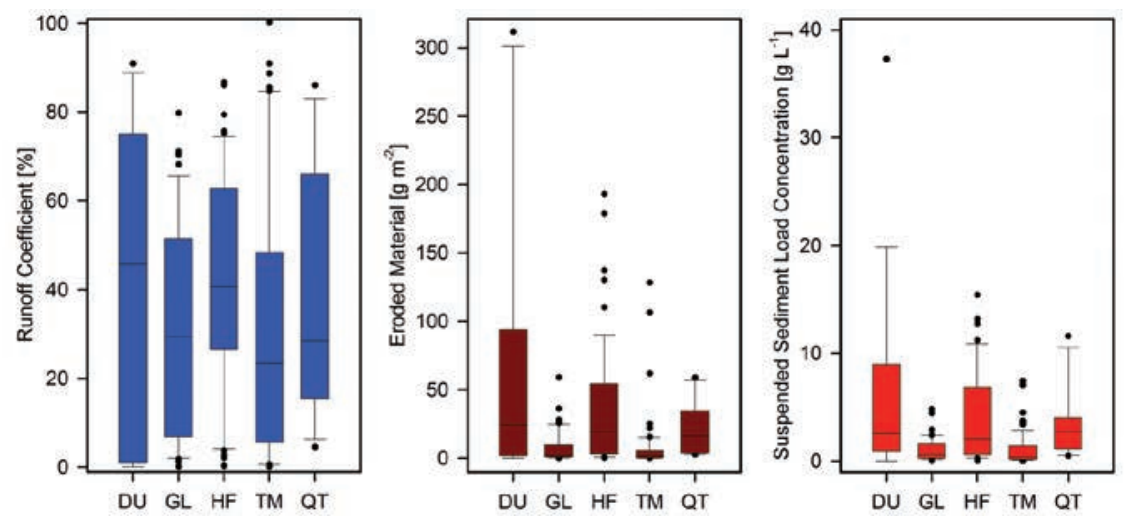

Figure 3. Runoff coefficient [\%]; eroded material [ $\mathrm{g} m-1]$ and suspended sediment load concentration [ $g \mathrm{~L}-1]$ in the rainfall simulation experiments. The lower and upper boundaries of each box represent the 25th and 75th percentiles, respectively, and the lower and upper

error bars represent the 10th and 90th percentiles, respectively. Solid line represents the median value. $D U=$ dunes; $G L=$ glacis; $H F=H o l o c e n e ~ f i l l i n g s ; T M=$ talus material and $Q T=$ Quaternary terraces.

Suspended sediment load concentrations reached $2.7 \mathrm{~g} \mathrm{~L}^{-1}$ on Holocene fillings and 2.6 $\mathrm{g} \mathrm{L}^{-1}$ on dunes and Quaternary terraces. On glacis and talus material lower concentrations of $1.6 \mathrm{~g} \mathrm{~L}^{-1}$ and $1.4 \mathrm{~g} \mathrm{~L}^{-1}$ were measured.

The data clearly show that in contrast to glacis and talus material, Holocene fillings, Quaternary terraces and dunes are highly susceptible to splash, interrill erosion and runoff generation (Table 2). 
Table 2. Relief ranking based on mean, median and upper maximum values of runoff coefficient, eroded material and suspended sediment load concentration measured in the rainfall experiments.

\begin{tabular}{lcccccccccc}
\hline \multirow{2}{*}{ Relief unit } & \multicolumn{2}{c}{ Runoff Coefficient } & \multicolumn{3}{c}{ Eroded Material } & \multicolumn{3}{c}{$\begin{array}{c}\text { Suspended Sediment } \\
\text { Load Concentration }\end{array}$} \\
\cline { 2 - 12 } & Median Mean & $\begin{array}{c}\text { Upper } \\
\text { max. }\end{array}$ & Median & Mean & $\begin{array}{c}\text { Upper } \\
\text { max. }\end{array}$ & $\begin{array}{c}\text { Median } \\
\text { Mean }\end{array}$ & $\begin{array}{c}\text { Upper } \\
\text { max. }\end{array}$ \\
\hline Dune & 1 & 2 & 1 & 1 & 1 & 1 & 3 & 1 & 2 \\
\hline Glacis & 3 & 5 & 4 & 4 & 5 & 4 & 4 & 5 & 5 \\
\hline Holocene filling & 2 & 1 & 2 & 2 & 2 & 2 & 1 & 2 & 1 \\
\hline Talus material & 5 & 4 & 5 & 5 & 4 & 5 & 5 & 4 & 4 \\
\hline Quaternary terraces & 4 & 3 & 3 & 3 & 3 & 3 & 2 & 3 & 3 \\
\hline
\end{tabular}

\subsection{Rill erosion}

The investigated rills are naturally developed, resulting in linear erosion forms that collect runoff from micro-watersheds of around $300 \mathrm{~m}^{2}$. Taking into account the length of the rills $(\sim 20 \mathrm{~m})$, the size of the observed surface exceeds one to two orders of magnitude the artificial plot size analyzed by the rainfall simulations.

The hydraulic activity of the rills studied in the glacis was very high with a median R-L factor of $5 \mathrm{LL}^{-1} \mathrm{~m}$ (Fig. 4) and a broad scattering. This means that we can find areas within the rills with very low infiltration rates. Here we can assume that the clays of the glacis d'accumulation, or the bedrock in the glacis d'érosion inhibit the infiltration. Although much less variable, the Holocene fillings show a similar median R-L factor, clearly influenced by surface crusting. In contrast, talus material allowed more water infiltration during the experiments, but a high variability of hydraulic activity was shown as well. The values on Quaternary terraces in southern Morocco were extremely low and homogeneous.
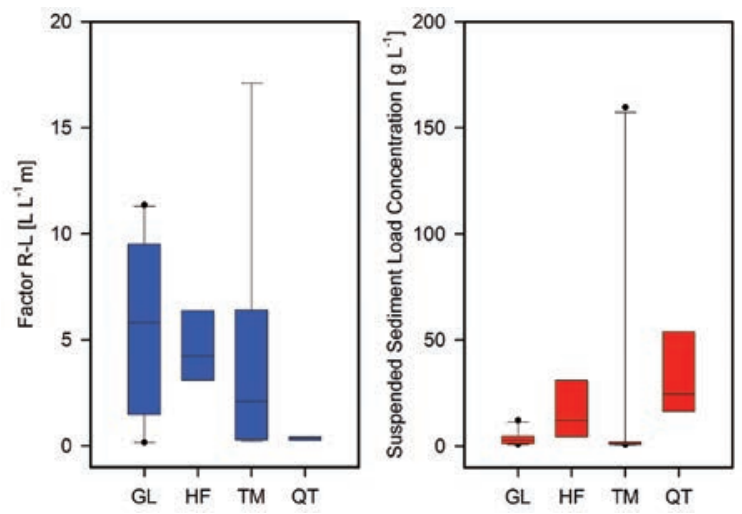

Figure 4. Factor $R-L\left[\begin{array}{lll}L & L-1 & m\end{array}\right]$ and measured suspended sediment load concentration [ $g$ L-1] in the rill experiments. Factor $R$ - $L$ is a specific runoff coefficient related to flow length as a value for hydraulic activity. Solid line represents the median value. The lower and upper boundaries of each box represent the 25th and 75th percentiles, respectively, and the lower and upper error bars represent the 10th and 90th percentiles, respectively. $G L=$ glacis; $H F=$ Holocene fillings;

$T M=$ talus material and $Q T=$ Quaternary terraces. 
On all relief units, suspended sediment load concentrations in rill experiments were an order of magnitude higher than the concentrations measured in the rainfall simulations. On terraces and also on the Holocene fillings of the Iberian Peninsula, we found the highest concentrations, thus, they behaved reverse to what was described in relation to hydraulic activity (Table 3 ). Similar to the rainfall simulation results, very low erosion values were measured on glacis and talus material.

The high hydraulic activity observed on the glacis indicates that these were incised by the runoff concentrated in the rills. Low suspended sediment load concentrations were counteracted by high water amounts flowing through the system. However, as described above, erosion in the rills was minimal. This suggests that the glacis do not continue developing under the present conditions.

Table 3. Relief ranking based on mean, median and upper maximum values of the $R$ - $L$ factor and suspended sediment load concentration measured in the rill experiments. Factor $R$ - $L$ is a specific runoff coefficient related to flow length as a value for hydraulic activity.

\begin{tabular}{lcccccc}
\hline \multirow{2}{*}{ Relief unit } & \multicolumn{3}{c}{ Factor R-L } & \multicolumn{3}{c}{$\begin{array}{c}\text { Suspended Sediment Load } \\
\text { Concentration }\end{array}$} \\
\cline { 2 - 8 } & Median & Mean & $\begin{array}{c}\text { Upper } \\
\text { max. }\end{array}$ & Median & Mean & $\begin{array}{c}\text { Upper } \\
\text { max. }\end{array}$ \\
\hline Dune & - & - & - & - & - & - \\
\hline Glacis & 1 & 1 & 1 & 3 & 4 & 3 \\
\hline Holocene filling & 2 & 2 & 3 & 2 & 3 & 2 \\
\hline Talus material & 3 & 3 & 2 & 4 & 2 & 4 \\
\hline Quaternary terraces & 4 & 4 & 4 & 1 & 1 & 1 \\
\hline
\end{tabular}

High erosion rates can be expected in Holocene fillings, as these showed high runoff factors in conjunction with high sediment concentrations. The high susceptibility to erosion detected on the Quaternary terraces, based on the measured sediment concentrations, can only be considered as potential in this case, since in this unit low runoff was produced resulting in a low transport distance.

\subsection{Gully erosion}

Gullies were studied in areas up to about 150 ha. The gully growth rate is the result of complex interactions of different processes and factors within a catchment and in the substrate package in which the gullies incise. Therefore, the variability of gully development was very high and varied between $0.07 \mathrm{~m}$ and $10 \mathrm{~m}$ per year (Table 4). Gullies can be considered as the consequence of rill development, and record the highest growth rates on glacis (Table 5). Gullies on dunes also showed a high activity, while the development on Holocene fillings was lower. Furthermore, observed gullies on Quaternary terraces showed the lowest values. This high level of activity can be explained by the considerable differences in the hydraulic activity of the concentrated flows. 
Table 4. Main characteristics of the monitored gullies.

Table modified from Marzolff and Ries (2007).

\begin{tabular}{|c|c|c|c|c|c|c|}
\hline Gully site & Relief unit & $\begin{array}{l}\text { Land use / } \\
\text { land cover }\end{array}$ & $\begin{array}{l}\text { Headcut } \\
\text { type }\end{array}$ & $\begin{array}{l}\text { Catchment } \\
\text { size [ha] }\end{array}$ & $\begin{array}{l}\text { Monitoring } \\
\text { [years] }\end{array}$ & $\begin{array}{l}\text { Headcut } \\
{\left[\mathrm{m} \mathrm{a}^{-1}\right]}\end{array}$ \\
\hline \multicolumn{7}{|c|}{ Northeast Spain } \\
\hline $\begin{array}{l}\text { Barranco de } \\
\text { las Lenas }\end{array}$ & $\begin{array}{l}\text { Holocene } \\
\text { filling }\end{array}$ & $\begin{array}{l}\text { abandoned fields/ } \\
\text { sparse matorral }\end{array}$ & $\begin{array}{l}\text { rilled- } \\
\text { abrupt }\end{array}$ & 21.00 & 11 & 0.07 \\
\hline $\begin{array}{l}\text { Barranco } \\
\text { Rojo }\end{array}$ & $\begin{array}{l}\text { Holocene } \\
\text { filling }\end{array}$ & $\begin{array}{l}\text { cereal fields/ } \\
\text { young fallow land }\end{array}$ & abrupt & 1.20 & 4 & 0.50 \\
\hline \multicolumn{7}{|c|}{ Southeast Spain } \\
\hline Salada 1 & $\begin{array}{l}\text { Holocene } \\
\text { filling }\end{array}$ & almond plantation & abrupt & 90.00 & 6 & 0.51 \\
\hline Salada 3 & $\begin{array}{l}\text { Holocene } \\
\text { filling }\end{array}$ & young fallow land & abrupt & 1.70 & 6 & 0.25 \\
\hline Salada 4 & $\begin{array}{l}\text { Holocene } \\
\text { filling }\end{array}$ & cereal fields & abrupt & 50.00 & 6 & 0.15 \\
\hline Luchena 1 & $\begin{array}{l}\text { Holocene } \\
\text { filling }\end{array}$ & $\begin{array}{l}\text { very sparse } \\
\text { matorral }\end{array}$ & abrupt & 0.30 & 4 & 0.13 \\
\hline Freila & $\begin{array}{l}\text { Holocene } \\
\text { filling }\end{array}$ & $\begin{array}{l}\text { rangeland/ } \\
\text { abandoned fields }\end{array}$ & abrupt & 5.00 & 2 & 0.25 \\
\hline Casablanca & $\begin{array}{l}\text { Holocene } \\
\text { filling }\end{array}$ & rangeland & $\begin{array}{l}\text { rilled- } \\
\text { abrupt }\end{array}$ & 0.70 & 2 & 0.17 \\
\hline \multicolumn{7}{|c|}{ South Morocco } \\
\hline $\begin{array}{l}\text { Foum eI } \\
\text { Hassane }\end{array}$ & $\begin{array}{l}\text { Quaternary } \\
\text { terraces }\end{array}$ & $\begin{array}{l}\text { loam terrace with } \\
\text { stone pavement }\end{array}$ & $\begin{array}{l}\text { rilled- } \\
\text { abrupt }\end{array}$ & 0.75 & 3 & 0 \\
\hline Icht & $\begin{array}{l}\text { Quaternary } \\
\text { terraces }\end{array}$ & loam terrace & abrupt & $\sim 150.00$ & 3 & 0.31 \\
\hline \multicolumn{7}{|c|}{ Burkina Faso } \\
\hline $\begin{array}{l}\text { Gorom- } \\
\text { Gorom }\end{array}$ & Glacis & $\begin{array}{l}\text { grazed Acacial } \\
\text { raddiana- } \\
\text { savannah }\end{array}$ & abrupt & $\sim 100.00$ & 2 & 9.85 \\
\hline Oursi & Dune & $\begin{array}{l}\text { rangeland on } \\
\text { dunes }\end{array}$ & abrupt & 0.30 & 4 & 3.16 \\
\hline
\end{tabular}

Table 5. Relief ranking based on gully-erosion rates. Ranked are the maximum annual gully growth $\left(R_{\text {max }}\right)$, the mean annual gully growth $\left(R_{\text {mean }}\right)$ and the gully growth (Area loss).

\begin{tabular}{lccc}
\multicolumn{1}{c}{ Relief unit } & $\mathbf{R}_{\text {max }}\left[\mathbf{m ~ a}^{-1}\right]$ & $\mathbf{R}_{\text {mean }}\left[\mathbf{m ~ a}^{-1}\right]$ & Area loss $\left[\mathbf{m ~ a}^{-1}\right]$ \\
\hline Dune & 2 & 2 & 2 \\
\hline Glacis & 1 & 1 & 1 \\
\hline Holocene filling & 3 & 3 & 3 \\
\hline Talus material & - & - & - \\
\hline Quaternary terraces & 4 & 4 & 4 \\
\hline
\end{tabular}




\section{Discussion}

The results highlight that the different relief units showed differences in process dynamics, as a result of their very different landscape histories and different morphological and substrate characteristics.

On the one hand, it is obvious that certain forms of erosion, such as gullies, may be present or absent in certain morphological environments. Those gullies are the result of a process chain and structures linked to the current conditions of land use, climate etc. (Seeger et al., 2009; Torri and Poesen, 2014). But their current increase also shows that the history and genesis of certain relief units are decisive for the appearance of gullies. Gully growth intensity depends clearly on the relief unit. Thus, we can confirm the idea that leads to the formation of Erosion Response Units

Although many authors have noted their importance, the contribution of rills to total soil erosion has been intensely discussed for decades (e. g. Auzet et al., 1993; Cerdan et al., 2002; Nouwakpo et al., 2016b). But their development, dynamics and generation processes are still not understood in their entirety and complexity (e. g. Govers et al., 2007; Wirtz et al., 2013b). Although often considered as precursor of gullies, rills showed a differentiated behavior on the different relief units: first, rills did not distinguish the relief units so clearly and, second, they also appeared in environments where gullies were not observed, such as the talus material. Within the gully systems, the intensity of erosion processes and sediment transport is very variable and gullies have also proved to be very difficult to quantify in the field (Castillo et al. 2012).

Our experiments allowed to identify differences in hydraulic and erosion dynamics between different relief units. In the case of the Quaternary terraces in southern Morocco, a clear difference between susceptibility to erosion and current erosion could be observed. Current erosion is greatly reduced on this unit because of the high infiltration rates. The units most affected by concentrated erosion were glacis and Holocene fillings.

Erosion rates and runoff produced by rainfall simulation experiments were highly variable within relief units. The detailed scale of this type of measurement makes it clear that some well-defined factors govern the generation of runoff and erosion (e. g. Arnáez et al., 2007; Cerdà et al., 1998; Le Bissonnais et al., 2005; Martínez-Murillo et al., 2013; Ries et al., 2014; Rodrigo Comino et al., 2016). Despite the very small size of the experimental plots $\left(0.28 \mathrm{~m}^{2}\right)$, it should be noted that rainfall simulation measurements give a very clear idea of process intensities in much larger scales. This confirms the results by Seeger (2007), indicating that the dependence of runoff generation and erosion intensity on individual soil surface characteristics is much more complex than those analyzed by other authors (e. g. Auzet et al., 2004; Le Bissonnais et al., 2005).

\section{Conclusions}

Our study provides the following conclusions: 1. Dunes and Holocene fillings are especially prone to splash, interrill erosion and surface runoff. 2. In contrast, glacis are currently incised by rills and gullies. 3. Quaternary loam terraces are the unit with the lowest geomorphodynamic activity. 
We conclude that the relief units show very different dominance of erosion processes and process intensities. The differentiation is more significant with increasing scale and complexity of erosion processes: gully growth varies much more between the different units than splash and interrill erosion do. Our results show that a traditional geomorphological mapping including relief unit classification can provide useful information to quantify and understand current erosion processes.

\section{Acknowledgements}

The research for this study was funded by the Deutsche Forschungsgemeinschaft (DFG). The authors are grateful to all participating students from the universities of Trier, Frankfurt am Main and Freiburg for their valuable help during field campaigns.

\section{References}

Anders, N.S., Seijmonsbergen, A.C., Bouten, W. 2011. Segmentation optimization and stratified object-based analysis for semi-automated geomorphological mapping. Remote Sensing of Environment 115, 2976-2985. http://doi.org/10.1016/j.rse.2011.05.007.

Anders, N.S., Seijmonsbergen, A.C., Bouten, W. 2009. Modelling channel incision and alpine hillslope development using laser altimetry data. Geomorphology 113, 35-46. http://doi. org/10.1016/j.geomorph.2009.03.022.

Andres, W., Ries, J., Seeger, M. 2002. Pre-Holocene sediments in the Barranco de las Lenas, Central Ebro Basin, Spain, as indicators for climate-induced fluvial activities. Quaternary International 93-94, 65-72. http://doi.org/10.1016/S1040-6182(02)00042-3.

Arnáez, J., Lasanta, T., Ruiz-Flaño, P., Ortigosa, L. 2007. Factors affecting runoff and erosion under simulated rainfall in Mediterranean vineyards. Soil and Tillage Research 93, 324-334. http://doi.org/10.1016/j.still.2006.05.013.

Auzet, A.-V., Poesen, J., Valentin, C. 2004. Editorial: soil surface characteristics: dynamics and impacts on soil erosion. Earth Surface Processes and Landforms 29, 1063-1064. http://doi. org/10.1002/esp.1101.

Auzet, A.V., Boiffin, J., Papy, F., Ludwig, B., Maucorps, J. 1993. Rill erosion as a function of the characteristics of cultivated catchments in the north of France. Catena 20, 41-62. http://doi. org/10.1016/0341-8162(93)90028-N.

Carr, M., Watkinson, D.A., Svendsen, J.C., Enders, E.C., Long, J.M., Lindenschmidt, K.-E. 2015. Geospatial modeling of the Birch River: Distribution of Carmine Shiner (Notropis percobromus) in Geomorphic Response Units (GRU). International Review of Hydrobiology 100, 129-140. http://doi.org/10.1002/iroh.201501789.

Casalí, J., Loizu, J., Campo, M.A., De Santisteban, L.M., Álvarez-Mozos, J. 2006. Accuracy of methods for field assessment of rill and ephemeral gully erosion. Catena 67, 128-138. http:// doi.org/10.1016/j.catena.2006.03.005.

Castillo, C., Pérez, R., James, M.R., Quinton, J.N., Taguas, E.V., Gómez, J.A. 2012. Comparing the accuracy of several field methods for measuring gully erosion. Soil Science Society of America Journal 76, 1319-1332. http://doi.org/10.2136/sssaj2011.0390.

Cerdà, A., González-Pelayo, Ó., Giménez-Morera, A., Jordán, A., Pereira, P., Novara, A., Brevik, E.C., Prosdocimi, M., Mahmoodabadi, M., Keesstra, S., García Orenes, F., Ritsema, C.J. 2016. Use of barley straw residues to avoid high erosion and runoff rates on persimmon plantations in Eastern Spain under low frequency-high magnitude simulated rainfall events. Soil Research 54 (2), 154-165. http://doi.org/10.1071/SR15092. 
Cerdà, A., Schnabel, S., Ceballos, A., Gómez-Amelia, D. 1998. Soil hydrological response under simulated rainfall in the Dehesa land system (Extremadura, SW Spain) under drought conditions. Earth Surface Processes and Landforms 23, 195-209. http://doi.org/10.1002/ (SICI) 1096-9837(199803)23:3<195::AID-ESP830>3.0.CO;2-I.

Cerdan, O., Le Bissonnais, Y., Couturier, A., Bourennane, H., Souchère, V. 2002. Rill erosion on cultivated hillslopes during two extreme rainfall events in Normandy, France. Soil and Tillage Research. 67, 99-108. http://doi.org/10.1016/S0167-1987(02)00045-4.

D’Oleire-Oltmanns, S., Marzolff, I., Peter, K., Ries, J. 2012. Unmanned Aerial Vehicle (UAV) for Monitoring Soil Erosion in Morocco. Remote Sensing 4, 3390-3416. http://doi.org/10.3390/ rs4113390.

Drăguţ, L., Schauppenlehner, T., Muhar, A., Strobl, J., Blaschke, T. 2009. Optimization of scale and parametrization for terrain segmentation: An application to soil-landscape modeling. Computers and Geosciences 35, 1875-1883. http://doi.org/10.1016/j.cageo.2008.10.008.

Eltner, A., Kaiser, A., Castillo, C., Rock, G., Neugirg, F., Abellán, A. 2016. Image-based surface reconstruction in geomorphometry - merits, limits and developments. Earth Surface Dynamics 4 (2), 359-389. http://doi.org/10.5194/esurf-4-359-2016.

Flügel, W.-A. 1995. Delineating hydrological response units by geographical information system analyses for regional hydrological modelling using PRMS/MMS in the drainage basin of the River Bröl, Germany. Hydrological Processes 9, 423-436. http://doi.org/10.1002/ hyp. 3360090313 .

Govers, G., Giménez, R., Van Oost, K. 2007. Rill erosion: Exploring the relationship between experiments, modelling and field observations. Earth-Science Reviews 84, 87-102. http://doi. org/10.1016/j.earscirev.2007.06.001.

Hellebrand, H., van den Bos, R. 2008. Investigating the use of spatial discretization of hydrological processes in conceptual rainfall runoff modelling: a case study for the meso-scale. Hydrological Processes 22, 2943-2952. http://doi.org/10.1002/hyp.6909.

Iserloh, T., Ries, J.B., Arnáez, J., Boix-Fayos, C., Butzen, V., Cerdà, A., Echeverría, M.T., Fernández-Gálvez, J., Fister, W., Geißler, C., Gómez, J.A., Gómez-Macpherson, H., Kuhn, N.J., Lázaro, R., León, F.J., Martínez-Mena, M., Martínez-Murillo, J.F., Marzen, M., Mingorance, M.D., Ortigosa, L., Peters, P., Regüés, D., Ruiz-Sinoga, J.D., Scholten, T., Seeger, M., Solé-Benet, A., Wengel, R., Wirtz, S. 2013a. European small portable rainfall simulators: A comparison of rainfall characteristics. Catena 110, 100-112. http://doi. org/10.1016/j.catena.2013.05.013.

Iserloh, T., Ries, J.B., Cerdà, A., Echeverría, M.T., Fister, W., Geißler, C., Kuhn, N.J., León, F.J., Peters, P., Schindewolf, M., Schmidt, J., Scholten, T., Seeger, M. 2013b. Comparative measurements with seven rainfall simulators on uniform bare fallow land. Zeitschrift für Geomorphologie Suppl. Issues 57, 11-26. http://doi.org/10.1127/0372-8854/2012/S-00085.

Iserloh, T., Fister, W., Seeger, M., Willger, H., Ries, J.B. 2012. A small portable rainfall simulator for reproducible experiments on soil erosion. Soil and Tillage Research 124, 131-137. http:// doi.org/10.1016/j.still.2012.05.016.

Kawabata, D., Bandibas, J. 2009. Landslide susceptibility mapping using geological data, a DEM from ASTER images and an Artificial Neural Network (ANN). Geomorphology 113, 97-109. Doi : 10.1016/j.geomorph.2009.06.006.

Le Bissonnais, Y., Cerdan, O., Lecomte, V., Benkhadra, H., Souchère, V., Martin, P. 2005. Variability of soil surface characteristics influencing runoff and interrill erosion. Catena, 62 , 111-124. http://doi.org/10.1016/j.catena.2005.05.001.

Märker, M. 2002. Regionale Erosionsmodellierung unter Verwendung des Konzepts der Erosion Response Units (ERU) am Beispiel zweier Flusseinzugsgebiete im südlichen Afrika. $\mathrm{PhD}-$ Thesis, Friedrich-Schiller-University of Jena, Chemistry and Geoscience Faculty. 
Martínez-Murillo, J.F., Nadal-Romero, E., Regüés, D., Cerdà, A., Poesen, J. 2013. Soil erosion and hydrology of the western Mediterranean badlands throughout rainfall simulation experiments: A review. Catena 106, 101-112. http://doi.org/10.1016/j.catena.2012.06.001.

Martins, F.M.G., Fernandez, H.M., Isidoro, J.M.G.P., Jordán, A., Zavala, L. 2016. Classification of landforms in Southern Portugal (Ria Formosa Basin). Journal of Maps 12, 422-430. http:// doi.org/ 10.1080/17445647.2015.1035346.

Marzolff, I., Ries, J.B., Poesen, J. 2011. Short-term versus medium-term monitoring for detecting gully-erosion variability in a Mediterranean environment. Earth Surface Processes and Landforms 36, 1604-1623. http://doi.org/10.1002/esp.2172.

Marzolff, I., Poesen, J. 2009. The potential of 3D gully monitoring with GIS using high-resolution aerial photography and a digital photogrammetry system. Geomorphology 111, 48-60. http:// doi.org/10.1016/j.geomorph.2008.05.047.

Marzolff, I., Ries, J.B. 2007. Gully erosion monitoring in semi-arid landscapes. Zeitschrift für Geomorphologie NF 51, 405-425. http://doi.org/10.1127/0372-8854/2007/0051-0405.

Meissner, A.G.N., Carr, M.K., Phillips, I.D., Lindenschmidt, K.-E. 2016. Using a Geospatial Model to Relate Fluvial Geomorphology to Macroinvertebrate Habitat in a Prairie RiverPart 2: Matching Family-Level Indices to Geomorphological Response Units (GRUs). Water 8, 42. http://doi.org/10.3390/w803107.

Merz, W., Bryan, R.B. 1993. Critical conditions for rill initiation on sandy loam Brunisols: laboratory and field experiments in southern Ontario, Canada. Geoderma 57, 357-385. http:// doi.org/10.1016/0016-7061(93)90050-U.

Minár, J., Evans, I.S. 2008. Elementary forms for land surface segmentation: The theoretical basis of terrain analysis and geomorphological mapping. Geomorphology 95, 236-259. http://doi. org/10.1016/j.geomorph.2007.06.003.

Müller, C., Hellebrand, H., Seeger, M., Schobel, S. 2009. Identification and regionalization of dominant runoff processes - a GIS-based and a statistical approach. Hydrology and Earth System Sciencies 13, 779-792. http://doi.org/10.5194/hess-13-779-2009.

Nouwakpo, S.K., Weltz, M.A., McGwire, K. 2016a. Assessing the performance of structurefrom-motion photogrammetry and terrestrial LiDAR for reconstructing soil surface microtopography of naturally vegetated plots. Earth Surface Processes and Landforms 41, 308-322. http://doi.org/10.1002/esp.3787.

Nouwakpo, S.K., Williams, C.J., Al-Hamdan, O.Z., Weltz, M.A., Pierson, F., Nearing, M. 2016 b. A review of concentrated flow erosion processes on rangelands: Fundamental understanding and knowledge gaps. International Soil and Water Conservation Research 4, 75-86. http:// doi.org/10.1016/j.iswcr.2016.05.003.

Peña Monné, J.L., Echeverría Arnedo, M.T., Petit-Maire, N., Lafont, R. 1993. Cronología e interpretación de las acumulaciones holocenas de la val de las Lenas (Depresión del Ebro, Zaragoza). Geographicalia 321-332.

Pirotti, F. 2013. State of the Art of Ground and Aerial Laser Scanning Technologies for HighResolution Topography of the Earth Surface. European Journal of Remote Sensing 46, 6678. http://doi.org/10.5721/EuJRS20134605.

Poesen, J. 1987. Transport of rock fragments by rill flow - a field study. Catena Suppl. 8, 35-54.

Prosdocimi, M., Burguet, M., Di Prima, S., Sofia, G., Terol, E., Rodrigo Comino, J. Cerdà, A., Tarolli, P., 2017. Rainfall simulation and Structure-from-Motion photogrammetry for the analysis of soil water erosion in Mediterranean vineyards. Science of the Total Environment 574, 204-215. http://doi.org/10.1016/j.scitotenv.2016.09.036.

Ries, J.B., Marzen, M., Iserloh, T., Fister, W. 2014. Soil erosion in Mediterranean landscapes - Experimental investigation on crusted surfaces by means of the Portable Wind and Rainfall Simulator. Journal of Arid Environments 100-101, 42-51. http://doi.org/10.1016/j. jaridenv.2013.10.006. 
Ries, J.B., Marzolff, I. 2003. Monitoring of gully erosion in the Central Ebro Basin by large-scale aerial photography taken from a remotely controlled blimp. Catena 50, 309-328. http://doi. org/10.1016/S0341-8162(02)00133-9.

Rodrigo Comino, J., Iserloh, T., Lassu, T., Cerdà, A., Keesstra, S.D., Prosdocimi, M., Brings, C., Marzen, M., Ramos, M.C., Senciales, J.M., Ruiz Sinoga, J.D., Seeger, M., Ries, J.B. 2016. Quantitative comparison of initial soil erosion processes and runoff generation in Spanish and German vineyards. Science of the Total Environment 565, 1165-1174. http://doi. org/10.1016/j.scitotenv.2016.05.163.

Scherrer, S., Naef, F., Faeh, A.O., Cordery, I. 2007. Formation of runoff at the hillslope scale during intense precipitation. Hydrology and Earth System Sciences 11, 907-922. http://doi. org/5194/hess-11-907-2007.

Schwanghart, W., Scherler, D. 2014. Short Communication: TopoToolbox 2 - MATLAB-based software for topographic analysis and modeling in Earth surface sciences. Earth Surface Dynamics 2, 1-7. http://doi.org/10.5194/esurf-2-1-2014.

Seeger, M., Marzolff, I., Ries, J.B. 2009. Identification of gully-development processes in semiarid NE-Spain. Zeitschrift für Geomorphologie 53, 417-431. http://doi.org/10.1127/03728854/2009/0053-0417.

Seeger, M. 2007. Uncertainty of factors determining runoff and erosion processes as quantified by rainfall simulations. Catena 71, 56-67. http://doi.org/10.1016/j.catena.2006.10.005.

Sidorchuk, A., Märker, M., Moretti, S., Rodolfi, G. 2003. Gully erosion modelling and landscape response in the Mbuluzi River catchment of Swaziland. Catena 50, 507-525. http://doi. org/10.1016/S0341-8162(02)00123-6.

Smith, M.J.,Paron, P., Griffiths, J.S. 2011. Geomorphological Mapping: Methods and Applications. Elsevier Science.

Stöcker, C., Eltner, A., Karrasch, P. 2015. Measuring gullies by synergetic application of UAV and close range photogrammetry - A case study from Andalusia, Spain. Catena 132, 1-11. http:// doi.org/10.1016/j.catena.2015.04.004.

Tarolli, P. 2014. High-resolution topography for understanding Earth surface processes: Opportunities and challenges. Geomorphology 216, 295-312. http://doi.org/10.1016/j. geomorph.2014.03.008.

Tarolli, P., Sofia, G., Calligaro, S., Prosdocimi, M., Preti, F., Dalla Fontana, G. 2015. Vineyards in Terraced Landscapes: New Opportunities from Lidar Data. Land Degradation \& Development 26, 92-102. http://doi.org/10.1002/ldr.2311.

Tarolli, P., Dalla Fontana, G. 2009. Hillslope-to-valley transition morphology: New opportunities from high resolution DTMs. Geomorphology 113, 47-56. http://doi.org/10.1016/j. geomorph.2009.02.006.

Torri, D., Poesen, J. 2014. A review of topographic threshold conditions for gully head development in different environments. Earth-Science Reviews 130, 73-85. http://doi.org/10.1016/j. earscirev.2013.12.006.

Wang, R., Zhang, S., Pu, L., Yang, J., Yang, C., Chen, J., Guan, C., Wang, Q., Chen, D., Fu, B., Sang, X. 2016. Gully Erosion Mapping and Monitoring at Multiple Scales based on MultiSource Remote Sensing Data of the Sancha River Catchment, Northeast China. International Journal of Geo-Information 5 (11), 200. http://doi.org/10.3390/ijgi5110200.

Wells, R.R., Momm, H.G., Bennett, S.J., Gesch, K.R., Dabney, S.M., Cruse, R., Wilson, G.V. 2016. A Measurement Method for Rill and Ephemeral Gully Erosion Assessments. Soil Science Society of America Journal 80, 203-214. http://doi.org/10.2136/sssaj2015.09.0320.

Wirtz, S., Seeger, M., Remke, A., Wengel, R., Wagner, J.-F., Ries, J.B. 2013a. Do deterministic sediment detachment and transport equations adequately represent the process-interactions in eroding rills? An experimental field study. Catena 101, 61-78. http://doi.org/10.1016/j. catena.2012.10.003. 
Wirtz, S., Seeger, M., Zell, A., Wagner, C., Wagner, J.-F., Ries, J.B. 2013b. Applicability of Different Hydraulic Parameters to Describe Soil Detachment in Eroding Rills. PLoS ONE 8 (5), e64861. http://doi.org/10.1371/journal.pone.0064861.

Wirtz, S., Iserloh, T., Rock, G., Hansen, R., Marzen, M., Seeger, M., Betz, S., Remke, A., Wengel, R., Butzen, V., Ries, J.B. 2012a. Soil Erosion on Abandoned Land in Andalusia: A Comparison of Interrill- and Rill Erosion Rates. International Scholarly Research Notices Soil Science 2012, 1-16. http://doi.org/10.5402/2012/730870.

Wirtz, S., Seeger, M., Ries, J.B. 2012b. Field experiments for understanding and quantification of rill erosion processes. Catena 91, 21-34. http://doi.org/10.1016/j.catena.2010.12.002.

Wirtz, S., Seeger, M., Ries, J.B. 2010. The rill experiment as a method to approach a quantification of rill erosion process activity. Zeitschrift für Geomorphologie 54, 47-64. http://doi. org/0.1127/0372-8854/2010/0054-0004. 